\title{
Dual-season and full-polarimetric C band SAR assessment for vegetation mapping in the Amazon várzea wetlands
}

\author{
Luiz Felipe de Almeida Furtado ${ }^{a}$,* Thiago Sanna Freire Silva ${ }^{\mathrm{b}}$, Evlyn Márcia Leão de Moraes Novo ${ }^{\text {a }}$ \\ a Divisão de Sensoriamento Remoto, Instituto Nacional de Pesquisas Espaciais (INPE), Avenida dos Astronautas 1758, Jardim da Granja, São José dos Campos, SP 12227-010, Brazil

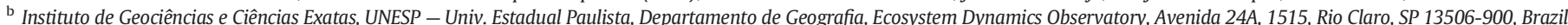

\section{A R T I C L E I N F O}

\section{Article history:}

Received 14 May 2015

Received in revised form 3 December 2015

Accepted 10 December 2015

Available online 22 December 2015

\section{Keywords:}

PolSAR

Wetlands

Polarimetric decomposition

Multitemporal

Mapping accuracy

\begin{abstract}
A B S T R A C T
This study answered the following questions: 1) Is polarimetric C-band SAR (PolSAR) more efficient than dualpolarization (dual-pol) C-band SAR for mapping várzea floodplain vegetation types, when using images of a single hydrological period? 2) Are single-season C-band PolSAR images more accurate for mapping várzea vegetation types than dual-season dual-pol C-band SAR images? 3) What are the most efficient polarimetric descriptors for mapping várzea vegetation types? We applied the Random Forests algorithm to classify dualpol SAR images and polarimetric descriptors derived from two full-polarimetric Radarsat-2 C-band images acquired during the low and high water seasons of Lago Grande de Curuai floodplain, lower Amazon, Brazil. We used the Kappa index of agreement ( $\kappa)$, Allocation Disagreement (AD) and Quantity Disagreement (QD), and Producer's and User's accuracy measurements to assess the classification results. Our results showed that single-season full-polarimetric C-band data can yield more accurate classifications than single-season dual-pol C-band SAR imagery and similar accuracies to dual-season dual-pol C-band SAR classifications. Still, dualseason PolSAR achieved the highest accuracies, showing that seasonality is paramount for obtaining high accuracies in wetland land cover classification, regardless of SAR image type. On average, single-season classifications of low-water periods were less accurate than high-water classifications, likely due to plant phenology and flooding conditions. Classifications using model-based polarimetric decompositions (such as Freeman-Durden, Yamaguchi and van $\mathrm{Zyl}$ ) produced the highest accuracies ( $\kappa$ greater than 0.8 ; $\mathrm{AD}$ ranging from $7.5 \%$ to $2.5 \%$; QD ranging from $15 \%$ to $12 \%$ ), while eigenvector-based decompositions such as Touzi and Cloude-Pottier had the worst accuracies ( $\kappa$ ranging from 0.5 to 0.7 ; AD greater than $10 \%$; QD smaller than $10 \%$ ). Vegetation types with dense canopies (Shrubs, Floodable Forests and Emergent Macrophytes), whose classification is challenging using C-band, were accurately classified using dual-season full-polarimetric SAR data, with Producer's and User's accuracies between $80 \%$ and $90 \%$. We conclude that full polarimetric C-band imagery can yield very accurate classifications of várzea vegetation ( $\kappa \sim 0.8, \mathrm{AD} \sim 3 \%$ and $\mathrm{QD} \sim 10 \%$ ) and can be used as an operational tool for forested wetland mapping.
\end{abstract}

(c) 2015 Elsevier Inc. All rights reserved.

\section{Introduction}

Várzeas are Amazon wetland ecosystems located on sediment-rich ("white water") river floodplains (Junk, 1997), covering $12 \%$ to $29 \%$ of the Amazon River basin (Melack \& Hess, 2010). Várzea vegetation types can be classified based on different criteria; Junk, Piedade, Schöngart, and Wittmann (2012) provide a comprehensive, hierarchical classification that initially divides várzea vegetation into two categories: Systems predominantly covered with (1) herbaceous plants or (2) woody plants. The first group is subdivided into three subgroups according to phenology, species composition and terrain elevation: (a) Low-lying areas mostly covered by annual grasses and herbs, (b) Low-lying areas mostly covered by perennial grasses and (c) High-

\footnotetext{
* Corresponding author.

E-mail address: furtadosere@gmail.com (L.F.A. Furtado).
}

lying disturbed areas with annual and perennial grasses and herbs. The second group is subdivided according to flood duration: (a) Low várzea forests (>3 months of flooding per year); (b) High várzea forests ( $<3$ months of flooding per year) and (c) Swamp forests (which may have permanent or multiannual flooding periods). Human-induced land cover changes often modify the expected spatial distribution of these plant communities, affecting the observed proportions between vegetation types (Junk et al., 2012; Junk, Bayley \& Sparks, 1989; Renó, Novo, Almeida-Filho and Suemitsu, 2011a; Renó, Novo, Suemitsu, Rennó and Silva, 2011b; Wittmann, Schöngart, \& Junk, 2010; Wittmann, Junk, \& Piedade, 2004).

Várzeas provide several ecosystem services that are important for the survival and quality of life of riverine human populations, such as water consumption, runoff reduction and slope stabilization, wood and forest products, and fisheries. Várzea ecosystems also host a wide range of distinctive fauna and flora, including the Amazonian manatee (Trichechus 
inunguis) (Arraut et al., 2010) and the pirarucu fish (Arapaima gigas) (Arantes, Castello, Cetra, \& Schilling, 2013), and have an important role in regional biogeochemical cycles, functioning as both sinks and sources of greenhouse gases $\left(\mathrm{CO}_{2}\right.$ and $\left.\mathrm{CH}_{4}\right)$. Despite its importance, várzea wetlands have been increasingly threatened by anthropogenic land use/ land cover change and economic appropriation of the space for agriculture, pastures and commercial fishery activities (Castello et al., 2013). About 54\% of the forest cover in the lower Amazon River várzea has been removed or replaced by other vegetation types and/or land uses between 1970 and 2008 (Renó et al., 2011a; Renó et al., 2011b).

Radar remote sensing has been an important tool for monitoring várzea ecosystems, especially given their extent and complexity. Synthetic Aperture Radar (SAR) microwaves can penetrate clouds, common in tropical and equatorial latitudes, and interact three-dimensionally with the vegetation, detecting both canopy structural characteristics and the flooding beneath it. SAR applications in várzea began in the 1980s with the Shuttle Imaging Radar (SIR-A, -B and -C) and other airborne missions (Hess, Melack, \& Simonett, 1990; Kasischke, Melack, \& Dobson, 1997), and progressed with several satellite systems such as ERS-1 and ERS-2 (C-band), JERS-1 and ALOS/PALSAR (L-band) and Radarsat (C-band) (Silva, Melack, Streher, Ferreira-Ferreira, \& de A. Furtado, 2015; Henderson \& Lewis, 2008), including the only comprehensive wetlands mapping for the entire Amazon Basin (Hess et al., 2015; Hess, Melack, Novo, Barbosa, \& Gastil, 2003; Melack \& Hess, 2010).

Most past platforms have only been capable of single- or dual-polarization (dual-pol) configurations, with limited potential for discriminating várzea vegetation types with subtle structural differences (Silva, Costa, \& Melack, 2010; Hess et al., 1990). Dual or multi-seasonal imagery (Hess et al., 2003; Martinez \& Le Toan, 2007; Silva et al., 2010) multiple incidence angles (Lang, Townsend, \& Kasischke, 2008; Marti-Cardona, Lopez-Martinez, Dolz-Ripolles, \& Bladè-Castellet, 2010) and/or multiple wavelengths (Costa, 2004; Costa, Niemann, Novo, \& Ahern, 2002; Hess et al., 1995) have all been explored to overcome such limitations, with the dual or multi-season approach offering the best balance between feasibility and effectiveness (Silva et al., 2015).

Modern spaceborne platforms such as TerraSAR-X ( $\mathrm{X}$ band), Radarsat-2 (C band) and ALOS-PALSAR-2 (L band) have full polarimetric or quad-pol imaging modes (PolSAR), as did a few previous platforms such as SIR-C (multi-frequency) and ALOS/PALSAR (L-band). Full polarimetric systems allow the reconstruction of the complete scattering matrix of the backscattered wave, permitting the calculation of polarimetric decompositions and other polarimetric descriptors (Lee \& Pottier, 2009) to quantify the contribution of different scattering mechanisms to the resulting backscattered signal. Several studies have highlighted the potential of PolSAR imagery for wetlands research (Brisco et al., 2013; Brisco, Kapfer, Hirose, Tedford, \& Liu, 2011; Gosselin, Touzi and Cavayas, 2013), but some questions remain underexplored in wetlands research, especially in várzea regions.

Therefore, we used two full-polarimetric C-band Radarsat- 2 images acquired in two different periods of the hydrological year to answer the following questions: 1 ) Is polarimetric C-band SAR (PolSAR) more efficient than dual-polarization (dual-pol) C-band SAR for mapping várzea floodplain vegetation types, when using images of a single hydrological period? 2) Are single-season C-band PolSAR images more accurate for mapping várzea vegetation types than dual-season dual-pol C-band SAR images? 3) What are the most efficient polarimetric descriptors for mapping várzea vegetation types?

\section{Methods}

\subsection{Study area}

Lago Grande de Curuai (Fig. 1) is a large floodplain lake complex located to the south of the city of Óbidos (Pará, Brazil). The Curuai floodplain has an annual and monomodal flooding regime, with peak flooding (high water season) occurring between May and June, and minimal flooding (low water season) occurring between November and December. Annual differences in water stage height between the two periods vary between 5 and $7 \mathrm{~m}$ at the deepest parts of the lake (Rudorff, Melack, \& Bates, 2014).

\subsection{Data acquisition and processing}

We used two full-polarimetric Radarsat-2 (RS2) images (C band, $\sim 5.6 \mathrm{~cm}$ wavelength) acquired in 2011-06-22 (high water season HW) and 2011-10-20 (low water season - LW), with approximately $8 \times 5 \mathrm{~m}$ (range $\times$ azimuth) spatial resolution and $25^{\circ}$ (SQ7) incidence angle. Other incidence angles ( $35^{\circ}-\mathrm{SQ} 14$ and $\left.45^{\circ}-\mathrm{SQ} 27\right)$ were assessed, but did not have significant effects on mapping accuracy. Furthermore, previous research recommends steep incidence angles for wetland/várzea mapping applications (Hess et al., 1990; Silva et al., 2008).

PolSAR processing consisted of (Fig. 2): (1) multilooking with 4 looks in azimuth and 1 in range, resulting in approximately $20 \times 20 \mathrm{~m}$ ground-range spatial resolution; (2) covariance (C) and coherence (T) matrix calculation; (3) speckle noise filtering using the Refined Lee adaptive filter with a $5 \times 5$ mask; (4) calculation of polarimetric decompositions (Table 1); (5) sigma-nought $\left(\sigma^{0}\right)$ calibration; and (6) RangeDoppler terrain correction and georeferencing. To preserve both spatial resolution and edges between surface targets, we did not use spatial averaging kernels to calculate polarimetric decompositions. Speckle was already mitigated by both multilooking and the use of speckle filtering.

We applied Range-Doppler terrain correction using the Shuttle Radar Topography Mission (SRTM) digital elevation model (DEM) (Jarvis, Reuter, \& Nelson, 2008). This DEM has $90 \mathrm{~m}$ spatial resolution and approximately $5 \mathrm{~m}$ vertical resolution (Bhang, Schwartz, \& Braun, 2007), and it was obtained at http://srtm.csi.cgiar.org/at its version 4 .

We georeferenced the RS2 images using a Landsat5/TM Global Land Survey 2000 (USGS, 2009) image, obtained at http://glcf.umd.edu/data/ landsat/. Polarimetric decompositions were performed using the Polarimetric SAR Data Processing and Educational Tool (PolSARPRO) software, version 4.2 (Pottier et al., 2009), which was also used for multilooking, speckle filtering and $\sigma^{0}$ calibration, the latter using image metadata, with $\pm 1 \mathrm{~dB}$ expected radiometric error. We performed Range-Doppler terrain correction using the Next ESA SAR Toolbox (NEST), version 4C1.1 (Engdahl, Minchella, Marinkovic, Veci, \& Lu, 2012).

\subsection{Image classification}

We grouped backscattering and polarimetric decomposition attributes into 27 different sets to serve as inputs for classification, based on the nature of the data and seasonality (high water, low water or dual-season, Table 2). It was thus possible to compare and assess classification accuracies between (a) single- and dual-season classifications, (b) dual-pol SAR $(\mathrm{HH}+\mathrm{HV})$ and PolSAR data, and (c) among different polarimetric attributes.

Prior to classification, we segmented all images using the multiresolution segmentation algorithm implemented in eCognition 8.0 , with the parameters Scale $=8$, Shape $=0.1$ and Compactness $=$ 0.5 . We defined these parameters based (a) on previous studies (Furtado, Silva, Fernandes, \& Novo, 2015) and (b) trial and error/heuristic approach. The selected parameters gave more importance to image radiometry (Shape $=0.1$ ) and balanced natural and human-made target contours (Compactness $=0.5$ ). Scale values between 5 and 50 were tested, and the value of 8 was selected as optimal, based on the visual interpretation of segmentation results (Fig. 3).

We created a single segmentation layer using dual-season $C$ matrix main diagonal images as inputs (corresponding to $\mathrm{HH}, \mathrm{HV}$ and VV polarizations) and used it for all classifications. The $\mathrm{C}$ matrix diagonal contains most of the scattering matrix information, has a higher signal-tonoise ratio than other polarimetric descriptors, and has better edge 

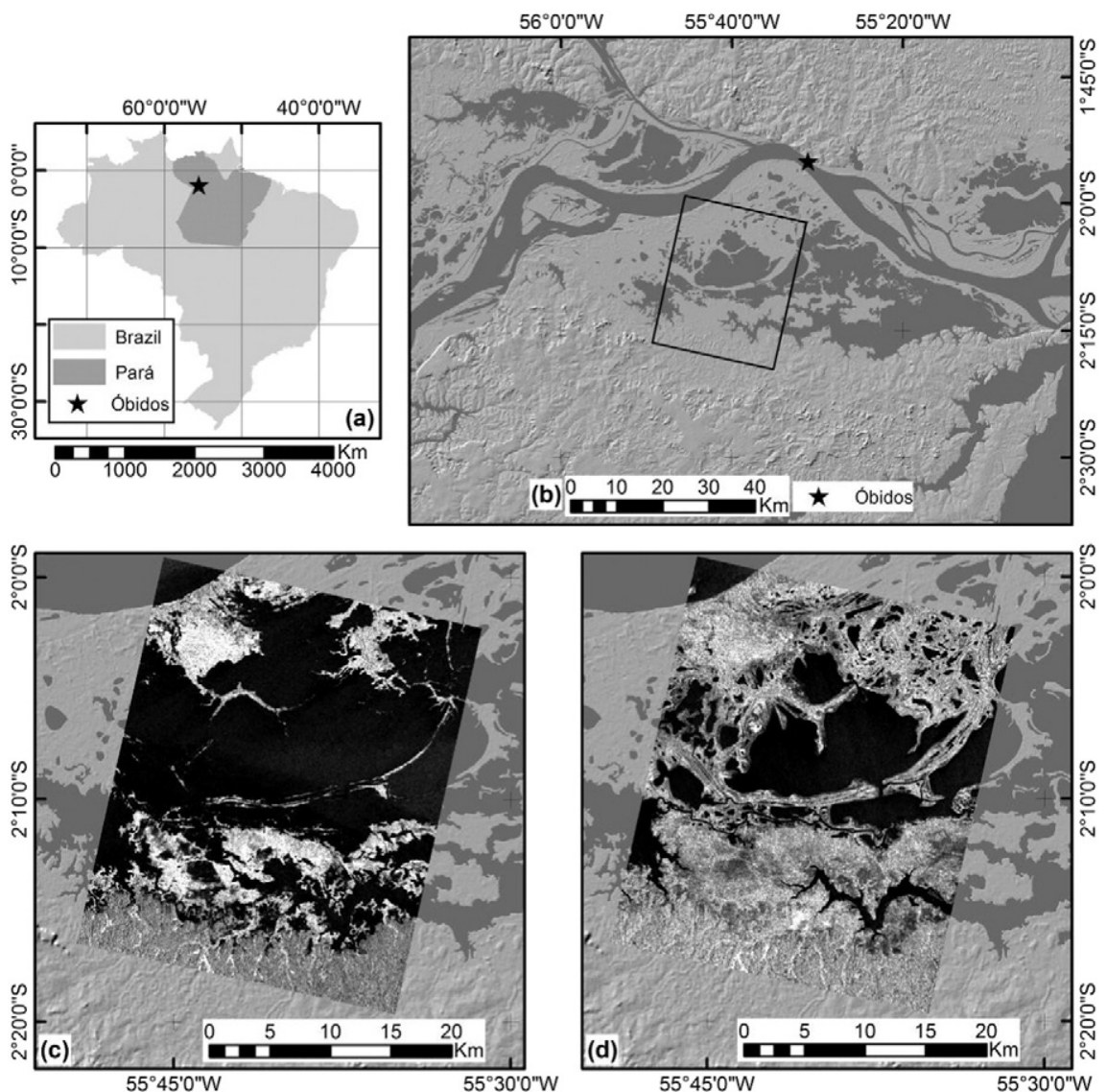

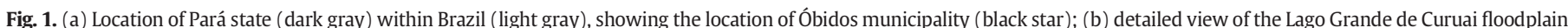

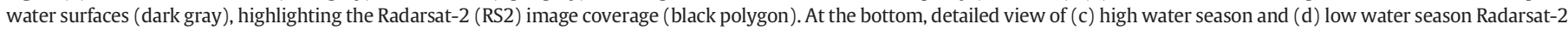
HH images extracted from POLSAR datasets. Radarsat-2 products are licensed for use by MacDonald, Dettwiler and Associates, Ltd.

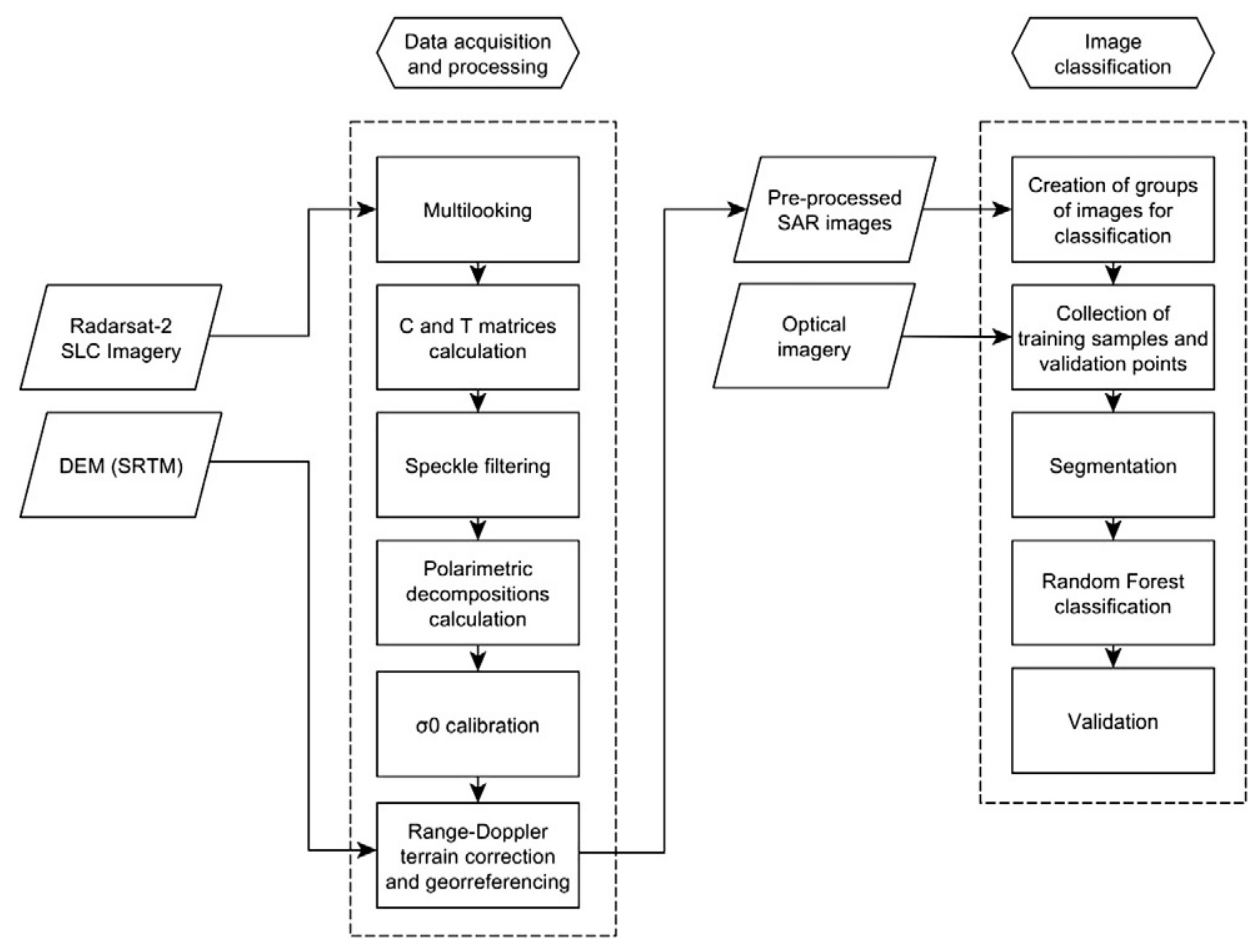

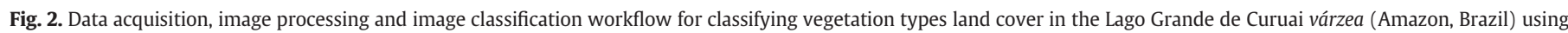
Radarsat-2 full polarimetric images. 
Table 1

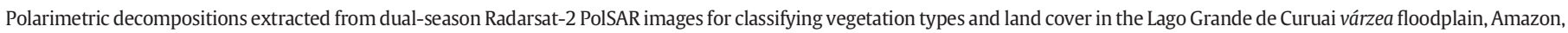
Brazil.

\begin{tabular}{|c|c|c|}
\hline $\begin{array}{l}\text { Polarimetric } \\
\text { decomposition }\end{array}$ & Symbol & Description \\
\hline \multicolumn{3}{|l|}{ Cloude-Pottier (Cloude \& Pottier, 1996) } \\
\hline$\alpha$ angle & $\alpha$ & Dominant scattering type \\
\hline Entropy & $H$ & Proportional importance of the dominant scattering type \\
\hline Anisotropy & $A$ & Proportional importance of secondary and tertiary scattering types \\
\hline \multicolumn{3}{|c|}{ Freeman-Durden (Freeman \& Durden, 1998) } \\
\hline Volumetric scattering & $\mathrm{FD}_{\mathrm{V}}$ & Proportion of volumetric scattering \\
\hline Double-bounce scattering & $\mathrm{FD}_{\mathrm{D}}$ & Proportion of double-bounce scattering \\
\hline Odd scattering & $\mathrm{FD}_{\mathrm{S}}$ & Proportion of odd (surface) scattering \\
\hline \multicolumn{3}{|l|}{ Touzi (Touzi, 2007) } \\
\hline Scattering type magnitude & $\alpha_{S 1 ;} \alpha_{S 2 ;} \alpha_{S 3 ;} \alpha_{S m}$ & $\begin{array}{l}\text { Angle of the symmetric scattering vector direction in the trihedral-dihedral basis. } \\
\qquad \text { Similar to Cloude-Pottier's } \alpha \text { angle }\end{array}$ \\
\hline Scattering type phase difference & $\Phi_{\alpha S 1}, \Phi_{\alpha S 2}, \Phi_{\alpha S 3}, \Phi_{\alpha S m}$ & Phase difference between trihedral and dihedral scattering \\
\hline Helicity & $\tau_{1} ; \tau_{2} ; \tau_{3} ; \tau_{\mathrm{m}}$ & Symmetric nature of target scattering. If $\tau=0$, target is isotropic \\
\hline Orientation angle & $\psi_{1} ; \psi_{2} ; \psi_{3} ; \psi_{\mathrm{m}}$ & Target tilt angle \\
\hline \multicolumn{3}{|c|}{ Yamaguchi (Yamaguchi, Yajima, \& Yamada, 2006) } \\
\hline Volumetric scattering & $\mathrm{Y}_{\mathrm{V}}$ & Proportion of volumetric scattering \\
\hline Double-bounce scattering & $Y_{D}$ & Proportion of double-bounce scattering \\
\hline Odd scattering & $\mathrm{Y}_{\mathrm{S}}$ & Proportion of odd (surface) scattering \\
\hline Helicity & $\mathrm{Y}_{\mathrm{H}}$ & Proportion of helix-type scattering \\
\hline \multicolumn{3}{|l|}{ Van Zyl (Vanzyl 1992) } \\
\hline Volumetric scattering & $\mathrm{VZ}_{\mathrm{V}}$ & Proportion of volumetric scattering \\
\hline Double-bounce scattering & $\mathrm{VZ}_{\mathrm{D}}$ & Proportion of double-bounce scattering \\
\hline Odd scattering & $\mathrm{VZ}_{\mathrm{S}}$ & Proportion of odd (surface) scattering \\
\hline
\end{tabular}

detection characteristics (Qi, Yeh, Li, \& Lin, 2012) (Fig. 3). After segmentation, we calculated the mean pixel value for all polarimetric descriptors in each image object and used it to compose the classification input sets.

We used the Random Forests (RF) algorithm (Breiman, 2001) to perform data classification, as implemented in the randomForest package (Liaw \& Wiener, 2002) of the R statistical software, version 3.1.1 (R Core Team, 2014). RF is a hierarchical classification algorithm that uses $n$ random decision trees to form a "random forest" that will classify the data based on the consensus among all trees. The RF classification procedure consists of: (1) defining a number $n_{\text {trees }}$ of random trees; (2) randomly selecting $m_{\text {try }}$ attributes for assessment at each individual tree node, and identifying the attribute that produces the purest leaves (i.e., the polarimetric descriptor that best discriminates the selected classes) within $m_{\text {try }}$; (3) building a single decision tree where all classes are discriminated in different nodes; (4) repeating this process $n_{\text {tree }}$ times, (5) building a consensus tree based on the most selected attributes, and (6) using this consensus tree to classify the input data.

The RF algorithm is (1) less susceptible to noisy data, (2) nonparametric, and thus supports data with varying statistical distributions (such as SAR intensities, phase and polarimetric attribute images), and (3) has only two settable parameters, reducing the subjectivity factor when comparing classification accuracies among different datasets (Barrett, Nitze, Green, and Cawkwell, 2014). Still, we assessed the impact of changes in $n_{\text {trees }}$ and $m_{\text {try }}$ on classification accuracy, and settled

Table 2

Input sets for classification of vegetation types and land cover in the Lago Grande de Curuai várzea floodplain, Amazon, Brazil. Each set was separately assessed for low-water, high-water, and dual-season conditions, totaling 27 input sets.

\begin{tabular}{lc}
\hline Abbreviation & Inputs for classification \\
\hline $\mathrm{HH}+\mathrm{HV}$ & $\mathrm{HH}+\mathrm{HV}$ (dual-pol) \\
$\mathrm{C}$ & C Matrix (including phase information) \\
$\mathrm{CP}$ & Cloude-Pottier \\
$\mathrm{TZ}$ & Touzi \\
$\mathrm{VZ}$ & Van Zyl \\
$\mathrm{YG}$ & Yamaguchi \\
$\mathrm{FD}$ & Freeman-Durden \\
$\mathrm{APD}$ & All polarimetric decompositions \\
$\mathrm{APC}$ & All images \\
\hline
\end{tabular}

on optimum values for each parameter by taking those that achieved the highest accuracies.

We assessed the parameter $m_{\text {try }}$ for the following values (using $n_{\text {trees }}=5000$ ): (a) one polarimetric attribute; (b) one third of the total number of polarimetric attributes; (c) the squared root of the total number of polarimetric attributes; (d) half of the total number of polarimetric attributes, (e) two thirds of the total number of polarimetric attributes; (f) all polarimetric attributes. After selecting the best $m_{\text {try }}$ value, we assessed the $n_{\text {trees }}$ parameter using the following values: $\left(\mathrm{a}^{\prime}\right)$ 250; (b') 500; (c') 1000; (d') 5000; ( $\left.e^{\prime}\right)$ 25,000 and ( $\left.f^{\prime}\right)$ 50,000. Each parameter was assessed taking into account the hydrological period and the total number of images used as input.

Changes in $m_{\text {try }}$ and $n_{\text {trees }}$ had little or no influence on classification accuracy, using either reduced $(\mathrm{HH}+\mathrm{HV})$ or increased numbers of inputs ( $C$ matrix and APC), with a maximum difference of 0.01 in $\kappa$ observed among all parameter combinations. Therefore, we set $m_{\text {try }}$ as the squared-root of the total number of inputs, as suggested by Breiman (2001), and $n_{\text {trees }}$ as 5000, based on previous SAR studies (FerreiraFerreira, Silva, Streher, Affonso, Furtado, Forsberg, \& Novo, 2014).

\subsection{Vegetation and land cover classes}

We defined six land-cover classes for this study (Table 3), described as follows: 1) Floodable forests (FF): Tree vegetation growing on higher floodplain areas and subject to shorter seasonal flooding periods; 2) shrubs (SB): Shrubs and/or early succession arboreal vegetation with sparse canopies and low height, subject to longer seasonal flooding; 3) emergent macrophytes (EM): Herbaceous plant communities dominated by palustrine grasses with high biomass and density levels, and subject to longer seasonal flooding periods; 4) floating macrophytes (FM): Free-floating herbaceous vegetation with lower biomass and/or sparse canopies; 5) open water (OW): Free water surfaces; and 6) várzea fields $(\mathrm{VF})$ : Floodplain areas that are completely under water during the high water season but emerge in the low water season, being colonized by terrestrial herbaceous plants.

Since most várzea locations are extremely hard to reach, we defined training and validation samples based on the interpretation of several ancillary data and our extensive knowledge of the location (Table 3 and Fig. 4). Our main sources of information were geotagged photographs and field notes acquired between 2013-10-18 and 2013-10- 

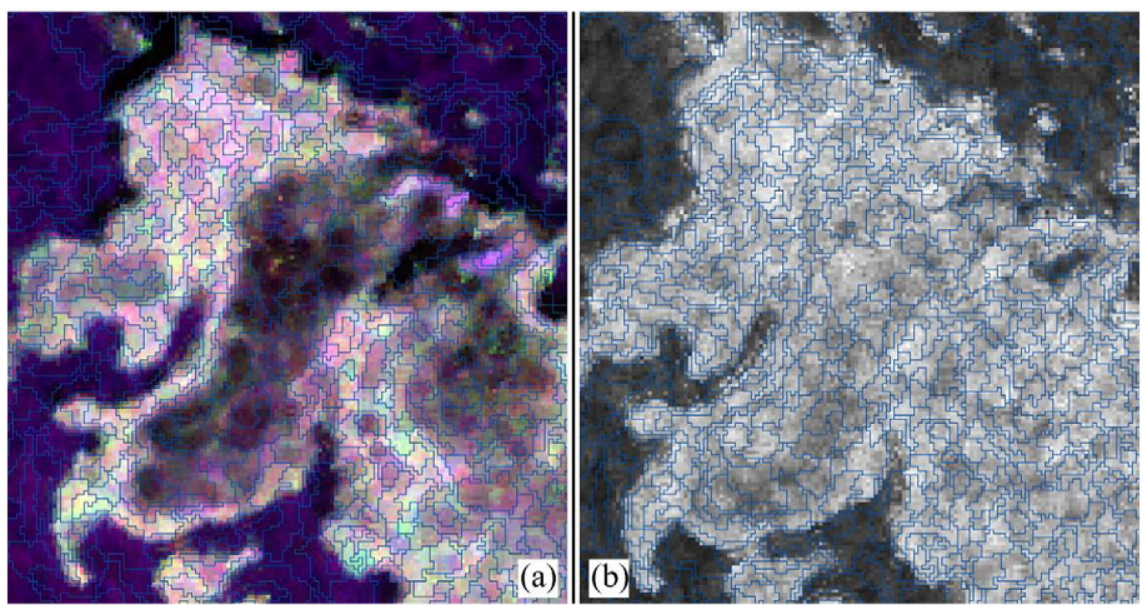

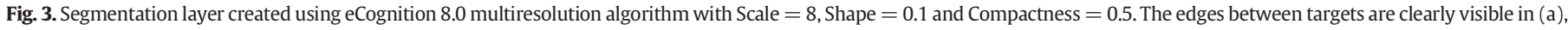

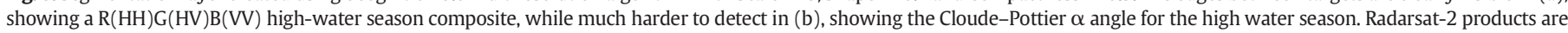

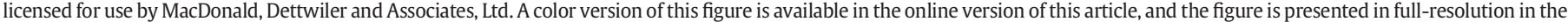
Electronic Supplementary Material.

29, and during a previous field trip from 2011-04-10 to 2011-04-15 (Arnesen et al., 2013). These data were complemented by Google Earth $^{\mathrm{TM}}$ and Microsoft Bing ${ }^{\mathrm{TM}}$ online high-resolution imagery and by Landsat5/TM scenes acquired during the same hydrological periods as the RS2 images (high-water: 2011-06-23 and 2011-07-25; lowwater: 2011-10-29). Despite the two year difference between imagery and field data acquisition, all georeferenced field descriptions and photographs obtained in 2013 matched the previous land cover and vegetation types observed on Landsat5/TM and RS2 images.

\subsection{Accuracy assessment}

We assessed overall classification accuracy using 292 ground truth samples (Fig. 4), and the Kappa (К) (Congalton, 1991), Quantity Disagreement (QD), and Allocation Disagreement (AD) (Pontius \& Millones, 2011) accuracy indexes. We also assessed class-based accuracy, using User's and Producer's percent accuracies (Congalton, 1991). Validation samples were selected using the same criteria described above for training samples.

Table 3

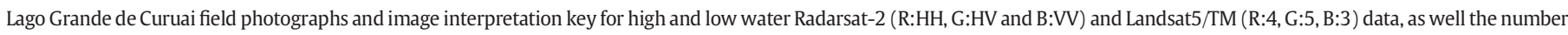

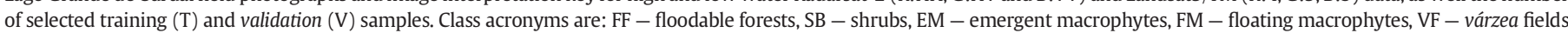

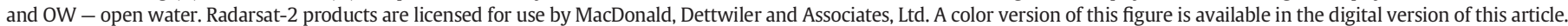

\begin{tabular}{|c|c|c|c|c|c|}
\hline Class & Field photographs & RS2 examples & Landsat5/TM examples & $\# \mathrm{~T}$ & $\# \mathrm{~V}$ \\
\hline $\mathrm{FF}$ & & & & 41 & 57 \\
\hline SB & & & & 33 & 32 \\
\hline EM & & & & 37 & 49 \\
\hline FM & & & & 23 & 30 \\
\hline ow & & & & 21 & 49 \\
\hline \multirow[t]{2}{*}{ VF } & & & & 36 & 75 \\
\hline & TOTAL & & & 191 & 292 \\
\hline
\end{tabular}




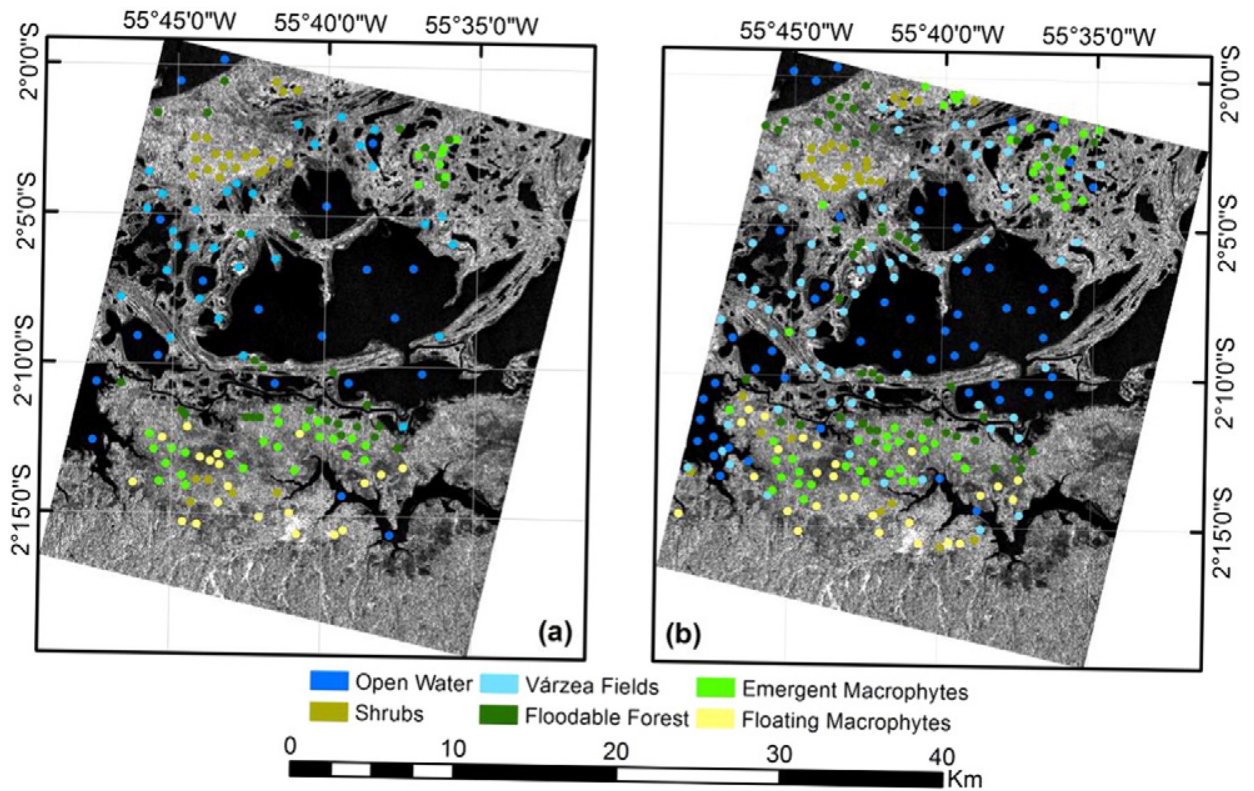

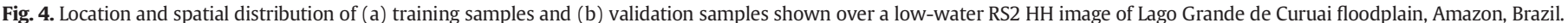

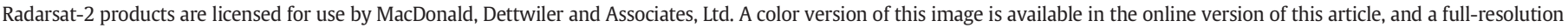
version is included in the Electronic Supplementary Material.
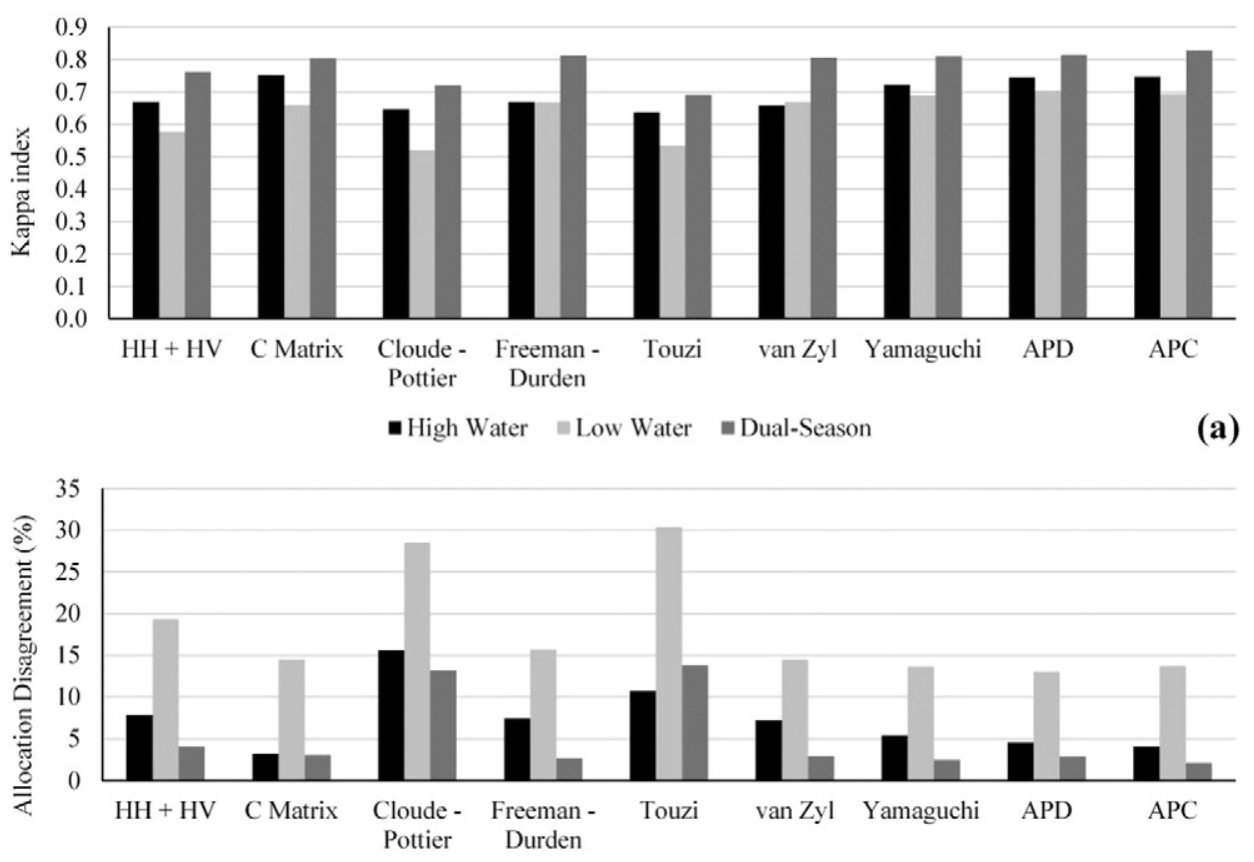

- High Water $=$ Low Water $=$ Dual-Season

(b)

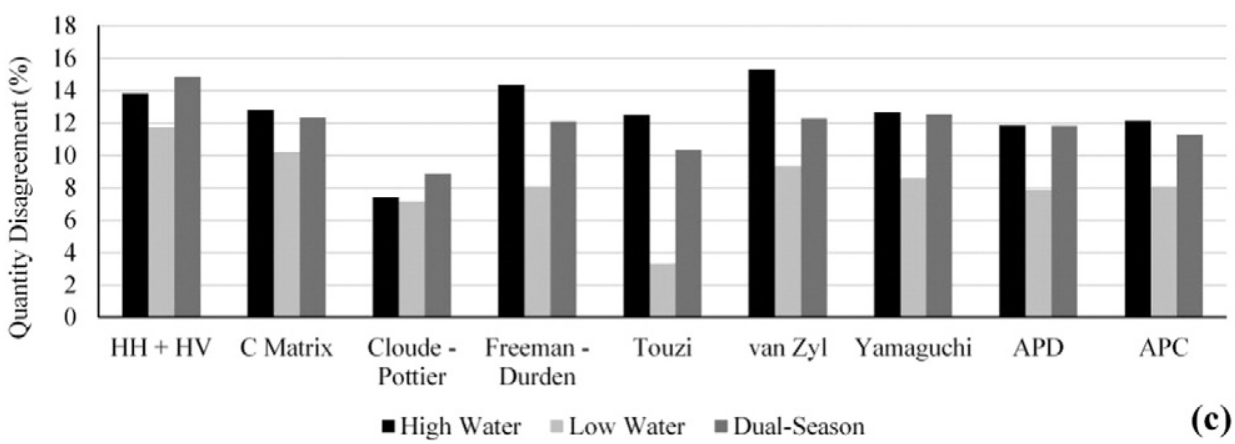

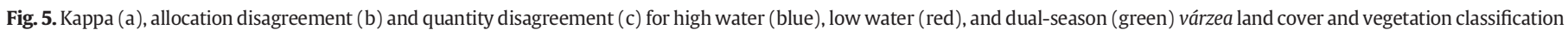
in the Lago Grande de Curuai floodplain, Amazon, Brazil. 
Initially, 400 validation points were randomly created using ArcGIS 10.3 , and only points with unambiguous interpretation were kept (292), ensuring that (a) every class had at least 30 validation points (Table 3 ) and (b) there was no spatial clustering, to avoid a positive bias. To assess the accuracy of each individual land-cover class, we compared the best and worst classification results obtained from all input sets, for a total of six classifications: two for each hydrological period (high and lowwater) and two for dual-season classification. This analysis aimed to understand the interaction between polarimetric attributes and hydrological conditions when classifying each vegetation/land cover type.

\section{Results}

\subsection{Polarimetric attribute classification accuracy}

For the HW season, $\mathrm{C}$ matrix was the most accurate PolSAR input $(\kappa=0.75 ; \mathrm{AD}=3.21 \% ; \mathrm{QD}=12.78 \%)$, followed by $\mathrm{APC}(\kappa=0.75$; $\mathrm{AD}=4.07 \% ; \mathrm{QD}=12.13 \%), \mathrm{APD}(\kappa=0.75 ; \mathrm{AD}=4.54 \% ; \mathrm{QD}=$ $11.84 \%$ ), and the model-based decompositions of Yamaguchi $(\kappa=$ $0.72 ; \mathrm{AD}=5.42 \% ; \mathrm{QD}=12.67 \%)$ and Freeman-Durden $(\kappa=0.67$; $\mathrm{AD}=7.42 \% ; \mathrm{QD}=14.35 \%$ ). The classification based on the Touzi decomposition had the lowest accuracy ( $\kappa=0.64, \mathrm{AD}=10.7 \%, \mathrm{QD}=$ 12.5\% (Fig. 5a, b and c, Fig. 6a and b).

On average, LW classifications were less accurate than HW, with the highest accuracy achieved by APD $(\kappa=0.70, \mathrm{AD}=13.03 \%$, QD $=$ 7.86\%) and the lowest accuracy by the Cloude-Pottier decomposition $(\kappa=0.52, \mathrm{AD}=28.53 \%, \mathrm{QD}=7.17 \%$ ). Although $\mathrm{QD}$ values were smaller for all LW classifications, they were disregarded as large AD errors can artificially decrease QD (Pontius \& Millones, 2011). Differences between the most and least accurate classifications were smaller for the LW season than for the HW season ( $\kappa=0.66$ to 0.70 ; $A D=15.7 \%$ to $13 \%$; $Q D=$ $11.73 \%$ to $8.1 \%$ ).

\subsection{Single-season vs. dual-season classification}

Dual-season classifications were systematically more accurate than single-season classifications. Almost all dual-season classifications had higher accuracies when compared to their single-season counterparts ( $\kappa=0.75$ or higher; $A D=4 \%$ or lower; $\mathrm{QD}$ ranging from $11 \%$ to $15 \%$ ), except for the Touzi ( $\kappa=0.69, \mathrm{AD}=13.79 \%, \mathrm{QD}=10.34 \%$ ) and
Cloude-Pottier ( $\kappa=0.72, \mathrm{AD}=13.17 \%, \mathrm{QD}=8.86 \%$ ) decompositions. The highest overall accuracy, considering all datasets, was achieved by the Dual Season APC dataset, i.e. all polarimetric decompositions plus $\mathrm{C}$ matrix images ( $\kappa=0.83, \mathrm{AD}=2.14 \%, \mathrm{QD}=11.28 \%$ ).

\subsubsection{Class-specific error assessment}

The use of dual-season imagery and/or the combination of several different polarimetric attributes brought the largest improvements in all class-specific accuracies (Fig. 7). In average, vegetation classes ( $\mathrm{SH}$, EM and FF) had a $30 \%$ to $40 \%$ increase in Producer's Accuracy and User's Accuracy when dual-season images and/or several different polarimetric descriptors (APC and APD classifications) were used. EM Producer's Accuracy increased from $46.4 \%$ to $89.2 \%$ and User's Accuracy increased from $26.5 \%$ to $67.3 \%$ between HW TZ and dual-season APD, respectively. For the SH class, Producer's Accuracy increased from $38.1 \%$ to $75 \%$ and User's Accuracy from $48.5 \%$ to $72.7 \%$ between HW TZ and dual-season APD, respectively. For the FF class, Producer's Accuracy increased from $48.6 \%$ to $79.1 \%$ and User's Accuracy increased from $64.3 \%$ to $94.6 \%$ between LW TZ and dual-season APD, respectively. Tables 4, 5 and 6 show the confusion matrices for the three most accurate classifications and Tables 7, 8 and 9 for the three least accurate classifications (all confusion matrices are available in the Electronic Supplementary Material).

\section{Discussion}

\subsection{PolSAR responses to vegetation dynamics}

Overall, our results confirm that PolSAR images are more efficient than dual-pol SAR images in mapping wetland land cover and vegetation types. PolSAR classification accuracies reported in the literature vary from 64\% (Brisco et al., 2011) to 95\% (Brisco et al., 2013), but more frequently between $75 \%$ and $90 \%$ (Ainsworth, Kelly, \& Lee, 2009; Garcia, Roberto, Mura, Johann, \& Kux, 2012; Lee, Grunes, \& Pottier, 2001; Millard \& Richardson, 2013; Qi et al., 2012; Sartori, Imai, Mura, Novo, \& Silva, 2011). The accuracies yielded in this study ranged from $\kappa \sim 0.5$ to 0.83 , AD from $~ 30 \%$ to $2 \%$ and QD from $15.3 \%$ to $3.33 \%$. We consider the combination of the Random Forests algorithm and PolSAR imagery to be very effective for mapping várzea vegetation types, even when using shortwave C-band images, which are known to be saturated by várzea vegetation types with dense canopies, similar structures, and

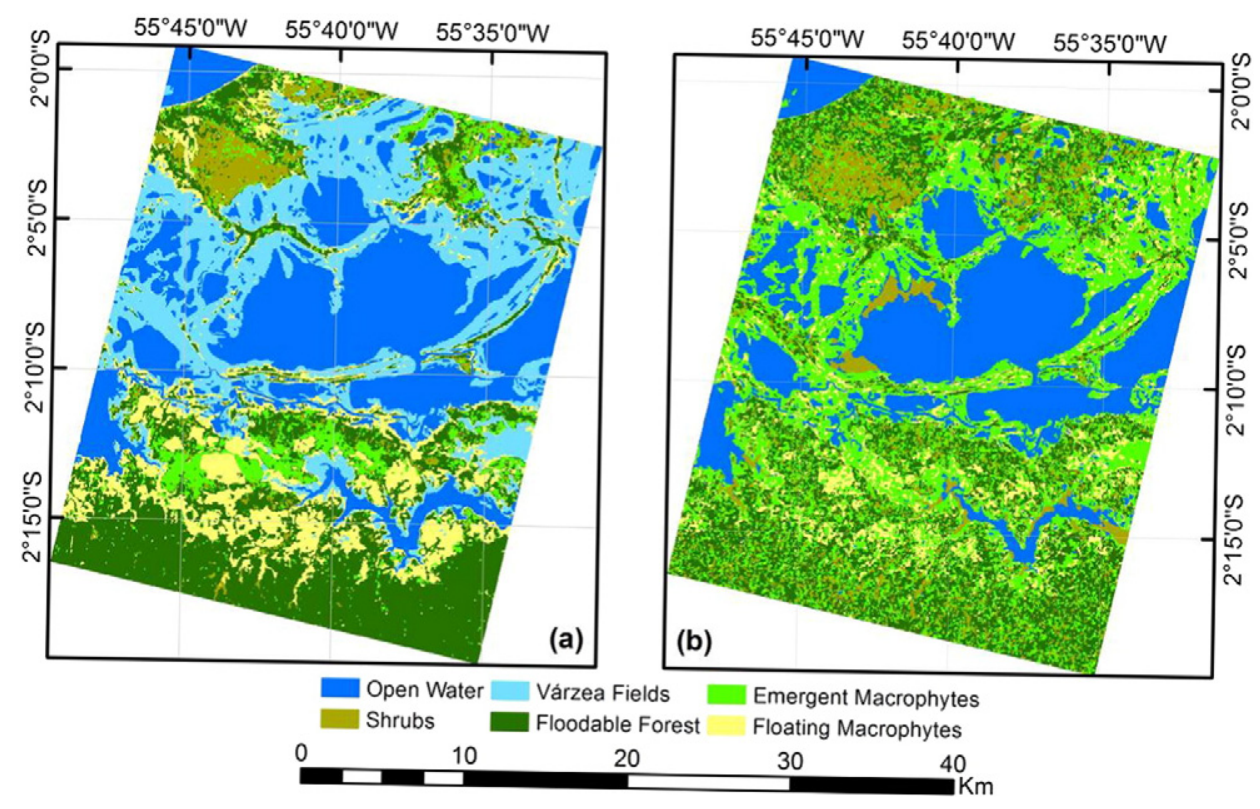

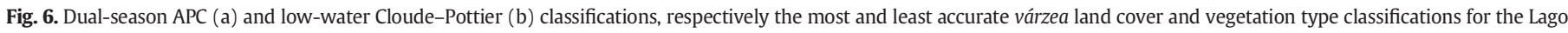

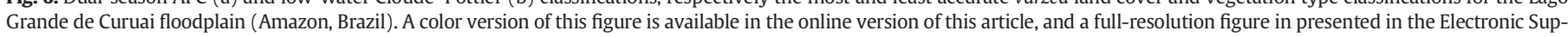
plementary Material. 

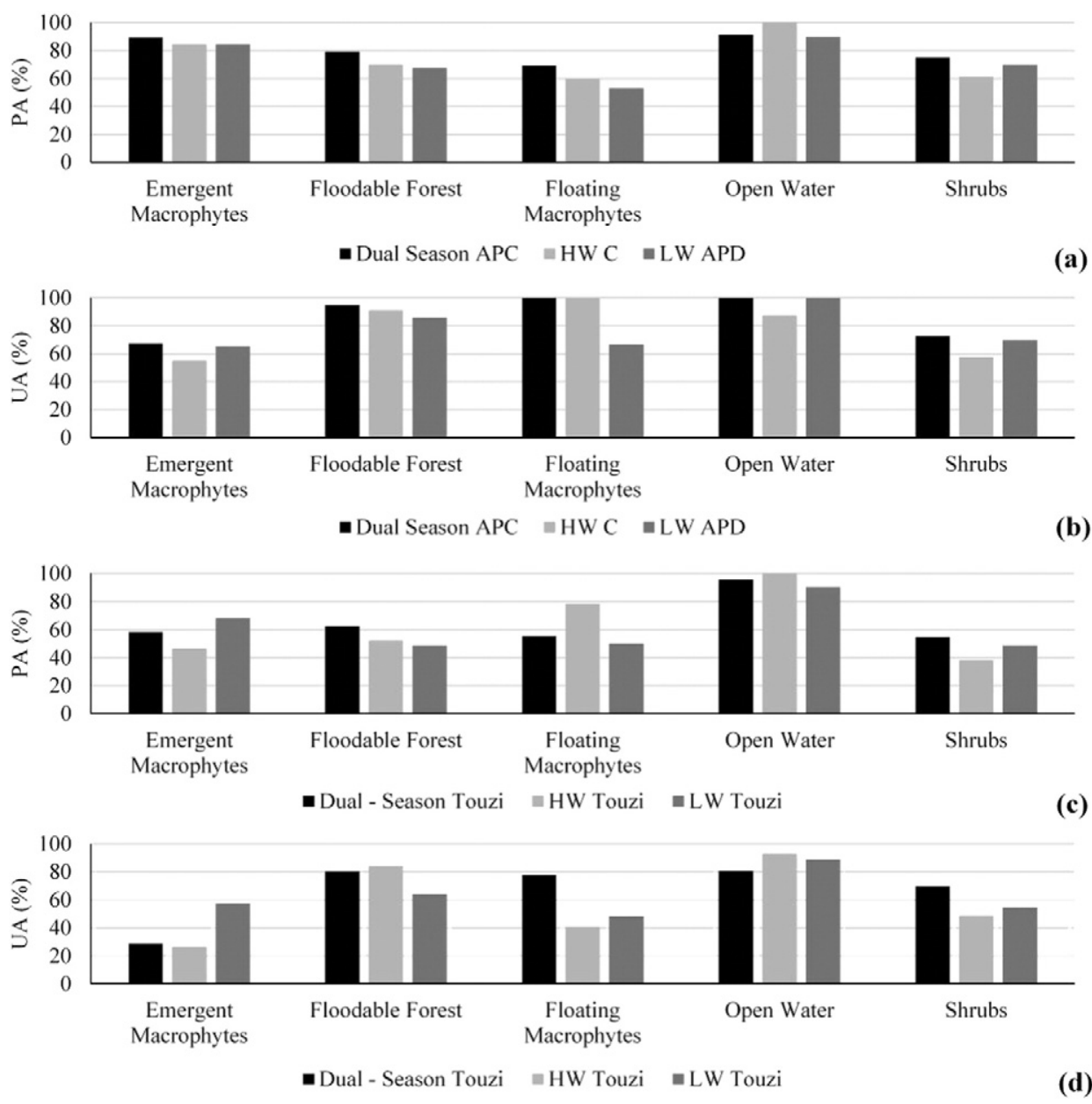

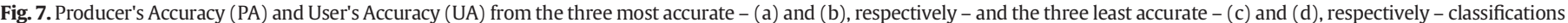

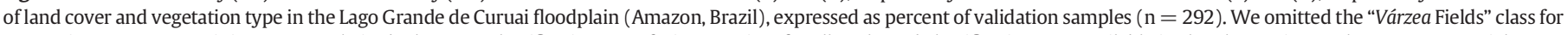
comparison purposes as it is present only in dual-season classifications. Confusion matrices for all evaluated classifications are available in the Electronic Supplementary Material.

similar backscattering mechanisms. Based on the results of this study, we can affirm that SAR and PolSAR images are a major source of information for várzea and wetland vegetation mapping, rather than a lessefficient alternative to optical imagery that should be used only when the latter is not available.

The polarimetric descriptors based on the decomposition of the $T$ matrix eigenvectors (e.g. Touzi and Cloude-Pottier) systematically yielded lower mapping accuracies than decompositions based on scattering models (e.g. Freeman-Durden and Yamaguchi). While the van Zyl polarimetric decomposition is an eigenvector-based decomposition (van Zyl, 1992), its descriptors are similar to those generated from scattering models based on polarimetric decompositions (double-bounce,

Table 4

Confusion matrix for dual-season all polarimetric decomposition plus C-Matrix (APC) classification, dual-season most accurate classification of Lago Grande de Curuai floodplain várzea. Land cover and vegetation classes are: EM - emergent macrophytes; FF floodable forest; FM - floating macrophytes; OW - open water, SH - shrubs and VF várzea fields.

\begin{tabular}{lccccccc}
\hline \multicolumn{2}{l}{ Dual-season APC } & \multicolumn{7}{l}{} \\
\hline Classes & EM & FF & FM & OW & SH & VF & Total \\
\hline EM & $\mathbf{3 3}$ & 0 & 0 & 0 & 4 & 0 & 37 \\
FF & 9 & $\mathbf{5 3}$ & 0 & 0 & 5 & 0 & 67 \\
FM & 1 & 1 & $\mathbf{2 7}$ & 0 & 0 & 10 & 39 \\
OW & 0 & 0 & 0 & $\mathbf{5 2}$ & 0 & 5 & 57 \\
SH & 6 & 2 & 0 & 0 & $\mathbf{2 4}$ & 0 & 32 \\
VF & 0 & 0 & 0 & 0 & 0 & $\mathbf{6 0}$ & 60 \\
Total & 49 & 56 & 27 & 52 & 33 & 75 & $\mathbf{2 9 2}$ \\
\hline
\end{tabular}

odd and volumetric scattering), and thereby we considered van Zyl as a model-based decomposition.

Model-based polarimetric decompositions lie on the real domain and estimate the intensity of each scattering mechanism occurring in a natural target (double-bounce, volumetric and odd-scattering). These polarimetric decompositions create one individual and independent descriptor for each backscattering mechanism, better describing class scattering patterns and yielding better accuracy indexes (Brisco et al., 2011; Van Beijma, Comber, \& Lamb, 2014).

Polarimetric decompositions based on eigenvector decomposition estimate target scattering mechanisms as both real and angular values. Despite the greater number of descriptors, they usually estimate the main backscattering mechanism of vegetation using a single or few components (such as Cloude-Pottier and Touzi $\alpha$ angles) and complement this

Table 5

Confusion matrix for high water $\mathrm{C}$ matrix classification, high water season most accurate classification of Lago Grande de Curuai floodplain várzea. Land cover and vegetation classes are: EM - emergent macrophytes; FF - floodable forest; FM - floating macrophytes; $\mathrm{OW}$ - open water and $\mathrm{SH}$ - shrubs.

\begin{tabular}{|c|c|c|c|c|c|c|}
\hline \multicolumn{7}{|c|}{ High water $\mathrm{C}$ matrix } \\
\hline Classes & EM & $\mathrm{FF}$ & FM & OW & $\mathrm{SH}$ & Total \\
\hline EM & 27 & 2 & 0 & 0 & 3 & 32 \\
\hline FF & 11 & 51 & 0 & 0 & 11 & 73 \\
\hline FM & 1 & 1 & 27 & 16 & 0 & 45 \\
\hline OW & 0 & 0 & 0 & 111 & 0 & 111 \\
\hline SH & 10 & 2 & 0 & 0 & 19 & 31 \\
\hline Total & 49 & 56 & 27 & 127 & 33 & 292 \\
\hline
\end{tabular}




\section{Table 6}

Confusion matrix for low water all polarimetric decomposition (APD) classification, low water season most accurate classification of Lago Grande de Curuai floodplain várzea. Land cover and vegetation classes are: EM - emergent macrophytes; FF - floodable forest; FM - floating macrophytes; $\mathrm{OW}$ - open water and $\mathrm{SH}$ - shrubs.

\begin{tabular}{lcccccc}
\hline \multicolumn{2}{l}{ Low water APD } & \multicolumn{7}{l}{} \\
\hline Classes & EM & FF & FM & OW & SH & Total \\
\hline EM & $\mathbf{8 1}$ & 3 & 9 & 0 & 3 & 96 \\
FF & 17 & $\mathbf{4 8}$ & 0 & 0 & 6 & 71 \\
FM & 15 & 0 & $\mathbf{1 8}$ & 0 & 1 & 34 \\
OW & 6 & 0 & 0 & $\mathbf{5 2}$ & 0 & 58 \\
SH & 5 & 5 & 0 & 0 & $\mathbf{2 3}$ & 33 \\
Total & 124 & 56 & 27 & 52 & 33 & $\mathbf{2 9 2}$ \\
\hline
\end{tabular}

estimate using other real and/or angular descriptors, such as Entropy and Phase-difference. As C-band is strongly attenuated by dense vegetation canopies, scattering intensities are similar for plant types with subtle structural differences (Gosselin, Touzi and Cavayas, 2013) and for densely vegetated floodplains (Costa, 2004; Henderson \& Lewis, 2008; Hess et al., 1990), hindering the ability of Cloude-Pottier $\alpha$ angle, Entropy and Anisotropy, and Touzi Phase-difference and $\alpha$ angle to detect subtle differences in backscattering mechanisms. The main, secondary and tertiary scattering mechanism types for each vegetation are similar and mainly differ in intensity, not in the nature of the scattering mechanism. Touzi Helicity and Orientation descriptors were of little use for discriminating várzea vegetation targets, as they were almost random. The low accuracy indexes obtained are strongly related to the wavelength and/or the similarity of the vegetation types, and the accuracy of Touzi and Cloude-Pottier based classifications can be higher when mapping less-similar wetland vegetation types (Millard \& Richardson, 2013) and/or when using longer wavelengths (Sartori et al., 2011).

\subsection{Dual-season classification}

Wetland environments, and várzeas in particular, are very dynamic landscapes, and the backscattering of each vegetation type is strongly affected by hydrological variation. In general, all dual-season classifications yielded higher accuracies than single-season images and were able to discriminate forest, woody and grass patches with similar structures but different phenology and flooding durations. As their backscattering mechanism changes in both intensity and type between the high and low water seasons, the RF classifier was able to detect seasonal backscattering patterns and accurately map these classes.

For the woody classes ( $\mathrm{SH}$ and $\mathrm{FF}$ ), the main noticeable difference between HW and LW backscattering was related to changes in double-bounce occurrence. This type of scattering occurred with more intensity in the SH class, composed by shorter woody individuals with less dense and more fragmented canopies, and subject to longer flooding durations. These characteristics make SH canopies less attenuating to the C-band signal and allow the microwaves to penetrate canopy gaps and thus interact more intensely with the flooding, increasing

\section{Table 7}

Confusion matrix for dual-season Touzi polarimetric decomposition classification, dualseason least accurate classification of Lago Grande de Curuai floodplain várzea. Land cover and vegetation classes are: EM - emergent macrophytes; FF - floodable forest; FM floating macrophytes; OW - open water, $\mathrm{SH}$ - shrubs and VF - várzea fields.

\begin{tabular}{lccccccc}
\hline \multicolumn{2}{l}{ Dual-season Touzi } & \multicolumn{7}{l}{} \\
\hline Classes & EM & FF & FM & OW & SH & VF & Total \\
\hline EM & $\mathbf{1 4}$ & 6 & 2 & 0 & 2 & 0 & 24 \\
FF & 16 & $\mathbf{4 5}$ & 4 & 0 & 7 & 0 & 72 \\
FM & 5 & 1 & $\mathbf{2 1}$ & 1 & 1 & 9 & 38 \\
OW & 0 & 0 & 0 & $\mathbf{4 2}$ & 0 & 2 & 44 \\
SH & 14 & 4 & 0 & 0 & $\mathbf{2 3}$ & 1 & 42 \\
VF & 0 & 0 & 0 & 9 & 0 & $\mathbf{6 3}$ & 72 \\
Total & 49 & 56 & 27 & 52 & 33 & 75 & $\mathbf{2 9 2}$ \\
\hline
\end{tabular}

\section{Table 8}

Confusion matrix for high water Touzi polarimetric decomposition classification, high water season least accurate classification of Lago Grande de Curuai floodplain várzea. Land cover and vegetation classes are: EM - emergent macrophytes; FF - floodable forest; FM - floating macrophytes; OW - open water and SH - shrubs.

\begin{tabular}{lcccccc}
\hline \multicolumn{7}{l}{ High water Touzi } \\
\hline Classes & EM & FF & FM & OW & SH & Total \\
\hline EM & $\mathbf{1 3}$ & 4 & 2 & 1 & 8 & 28 \\
FF & 18 & $\mathbf{4 7}$ & 11 & 5 & 9 & 90 \\
FM & 0 & 0 & $\mathbf{1 1}$ & 3 & 0 & 14 \\
OW & 0 & 0 & 0 & $\mathbf{1 1 8}$ & 0 & 118 \\
SH & 18 & 5 & 3 & 0 & $\mathbf{1 6}$ & 42 \\
Total & 49 & 56 & 27 & 127 & 33 & $\mathbf{2 9 2}$ \\
\hline
\end{tabular}

double-bounce occurrence. Conversely, double-bounce occurrence is less intense for the FF class, composed by taller trees with denser canopies and found on the highest elevations within the várzea, thus having floods with shorter durations and heights.

Double-bounce scattering in herbaceous/grasses targets had similar intensities to woody classes, and in single-season classifications, there was a large overlap in backscattering from all floodable vegetation classes. During the low water season, double-bounces may still occur in areas that are flooded for longer periods or are quasi-permanent flooded, such as areas of Montrichardia spp. occurrence. This behavior may explain part of the confusion between EM and SH classes, as these classes have longer flooding periods and therefore similar temporal backscattering signatures. Volumetric scattering intensity for herbaceous plants/grasses, comprised mainly by the EM class, is also similar to those observed in woody vegetation, but seasonal changes were more detectable due their annual growth cycle.

Several studies highlight the importance of dual- and multi-seasonal remote sensing data for land cover classification of várzea and other wetlands (Costa, 2004; Kwoun \& Lu, 2009; Marti-Cardona et al., 2010; Silva et al., 2010). Several of these studies analyze the temporal backscattering signatures of plant communities and/or other targets without attempting classification (Cable, Kovacs, Shang, \& Jiao, 2014; Koch, Schmid, Reyes, \& Gumuzzio, 2012). Other studies use dual- or multiseasonal information to obtain a single best classification, but there is little discussion about the impacts of seasonality and the selected dates used in classification accuracy (Evans \& Costa, 2013). Few studies truly investigate and discuss the impacts of date choice on classification accuracy, or attempt to identify optimum date combinations (Hess et al., 2003; Jiao et al., 2014). Our study thus contributes by quantifying the impacts of both (1) seasonality and (2) polarimetric information on classification accuracy, when combined or not, reinforcing the results of previous studies on dual- or multi-seasonal SAR/ PolSAR wetland mapping.

\section{Conclusion}

Our results show that single-season full-polarimetric SAR can achieve classification accuracies that are similar or, in some cases,

\section{Table 9}

Confusion matrix for low water Touzi polarimetric decomposition classification, low water season lest accurate classification of Lago Grande de Curuai floodplain várzea. Land cover and vegetation classes are: EM - emergent macrophytes; FF - floodable forest; FM floating macrophytes; $\mathrm{OW}$ - open water and $\mathrm{SH}$ - shrubs.

\begin{tabular}{lcccccc}
\hline \multicolumn{2}{l}{ Low water Touzi } & \multicolumn{7}{l}{} \\
\hline Classes & EM & FF & FM & OW & SH & Total \\
\hline EM & $\mathbf{7 1}$ & 14 & 10 & 3 & 6 & 104 \\
FF & 27 & $\mathbf{3 6}$ & 3 & 0 & 8 & 74 \\
FM & 12 & 0 & $\mathbf{1 3}$ & 0 & 1 & 26 \\
OW & 4 & 0 & 1 & $\mathbf{4 6}$ & 0 & 51 \\
SH & 10 & 6 & 0 & 3 & $\mathbf{1 8}$ & 37 \\
Total & 124 & 56 & 27 & 52 & 33 & $\mathbf{2 9 2}$ \\
\hline
\end{tabular}


higher to those achievable by dual-season dual-pol SAR classifications, especially during the high water season $(\kappa=0.7-0.8$; $A D=3-5 \%$ and $\mathrm{QD}=10-15 \%)$. Therefore, the use of PolSAR images may reduce the need for multiple season imagery, reducing overall acquisition costs and enabling detailed assessment of vegetation cover at any chosen period of the hydrological cycle.

Still, várzea plant communities are very similar in terms of structure and phenology, and dual-seasonal PolSAR data was capable of achieving the highest classification accuracies for all classes, combining the better structural discrimination achieved by PolSAR with the hydrological and phenological information brought by dual-season data. Model-based decompositions and, to a lesser degree, the linear polarizations present in the C-matrix stood as the most accurate polarimetric descriptors for discriminating land cover and vegetation classes in várzea floodplains, for both single and dual-season images.

PolSAR data in all main SAR wavelengths ( $\mathrm{C}, \mathrm{X}$ and $\mathrm{L}$ bands) are readily available for commercial and scientific uses, and our results can help guide data acquisition strategies by research institutions, government agencies and the private sector. We were able to achieve very accurate classifications in this study ( $\kappa>0.8, \mathrm{AD}<3 \%$ and $\mathrm{QD}<10 \%$ ), showing that operational uses of PolSAR data for wetland mapping are a reality. The methods described in this study can be applied to generate accurate vegetation maps, contributing to improve habitat distribution, biomass and productivity, and greenhouse gas emission estimates, for both herbaceous and forest vegetation, contributing to the understanding of climate and land cover change impacts in the Amazon várzea and similar wetlands.

\section{Acknowledgments}

L.F.A. Furtado thanks INPE and CNPq for the granted PCI-DC fellowship, and CAPES for the master's degree fellowship. Field data collection was funded by the Graduate Program in Remote Sensing of the National Institute for Space Research (INPE) and by grant \#2011/23594-8, São Paulo Research Foundation (FAPESP). TSF Silva received postdoctoral support from grant \#2010/11269-2, São Paulo Research Foundation (FAPESP), during part of the study, and is currently funded by CNPq grant \#458038/2013-0. We thank the Canadian Space Agency (CSA) for the Radarsat-2 images granted to TSF Silva by the Science and Operational Applications Research (SOAR) program, project number 5052. Radarsat-2 data and products are licensed by MacDonald, Dettwiler and Associates, Ltd.

\section{Appendix A. Supplementary data}

Supplementary data to this article can be found online at http://dx. doi.org/10.1016/j.rse.2015.12.013.

\section{References}

Ainsworth, T. L., Kelly, J. P., \& Lee, J. S. (2009). Classification comparisons between dualpol, compact polarimetric and quad-pol SAR imagery. ISPRS Journal of Photogrammetry and Remote Sensing, 64(5), 464-471. http://dx.doi.org/10.1016/j. isprsjprs.2008.12.008.

Arantes, C. C., Castello, L., Cetra, M., \& Schilling, A. (2013). Environmental influences on the distribution of arapaima in Amazon floodplains. Environmental Biology of Fishes, 96(10-11), 1257-1267. http://dx.doi.org/10.1007/s10641-011-9917-9.

Arnesen, A. S., Silva, T. S. F., Hess, L. L., Novo, E. M. L. M., Rudorff, C. M., Chapman, B. D., \& McDonald, K. C. (2013). Monitoring flood extent in the lower Amazon River floodplain using ALOS/PALSAR ScanSAR images. Remote Sensing of Environment, 130 51-61. http://dx.doi.org/10.1016/j.rse.2012.10.035.

Arraut, E. M., Marmontel, M., Mantovani, J. E., Novo, E. M. L. M., Macdonald, D. W., \& Kenward, R. E. (2010). The lesser of two evils: Seasonal migrations of Amazonian manatees in the Western Amazon. Journal of Zoology, 280(3), 247-256. http://dx. doi.org/10.1111/j.1469-7998.2009.00655

Barrett, B., Nitze, I., Green, S., \& Cawkwell, F. (2014). Assessment of multi-temporal, multisensor radar and ancillary spatial data for grasslands monitoring in Ireland using machine learning approaches. Remote Sensing of Environment, 152(529), 109-124. http://dx.doi.org/10.1016/j.rse.2014.05.018.
Bhang, K. J., Schwartz, F. W., \& Braun, A. (2007). Verification of the vertical error in C-band SRTM DEM using ICESat and Landsat-7, Otter Tail County, MN. IEEE Transactions on Geoscience and Remote Sensing, 45(1), 36-44.

Breiman, L. (2001). Random forests. European Journal of Mathematics, 45(1), 5-32.

Brisco, B., Kapfer, M., Hirose, T., Tedford, B., \& Liu, J. (2011). Evaluation of C-band polarization diversity and polarimetry for wetland mapping. Canadian Journal of Remote Sensing, 37(1), 82-92. http://dx.doi.org/10.5589/m11-017.

Brisco, B. Li, K., Tedford, B, Charbonneau, F, Yun, S., \& Murnaghan, K. (2013) Compact polarimetry assessment for rice and wetland mapping. International Journal of Remote Sensing, 34(6), 1949-1964. http://dx.doi.org/10.1080/01431161.2012.730156.

Cable, J. W., Kovacs, J. M., Shang, J., \& Jiao, X. (2014). Multi-temporal polarimetric RADARSAT-2 for land cover monitoring in northeastern Ontario, Canada. Remote Sensing, 6(3), 2372-2392. http://dx.doi.org/10.3390/rs6032372.

Castello, L., Mcgrath, D. G., Hess, L. L., Coe, M. T., Lefebvre, P. A., Petry, P., ... Arantes, C. C. (2013). The vulnerability of Amazon freshwater ecosystems. Conservation Letters, 6(4), 217-229. http://dx.doi.org/10.1111/conl.12008.

Cloude, S. R., \& Pottier, E. (1996). A review of target decomposition theorems in radar polarimetry. IEEE Transactions on Geoscience and Remote Sensing, 34(2), 498-518.

Congalton, R. G. (1991). A review of assessing the accuracy of classifications of remotely sensed data. Remote Sensing of Environment, 37(1), 35-46. http://dx.doi.org/10. 1016/0034-4257(91)90048-B.

Core Team, R. (2014). R: A language and environment for statistical computing. Vienna, Austria: R Foundation for Statistical Computing (Retrieved from http://r-project.org).

Costa, M. P. F. (2004). Use of SAR satellites for mapping zonation of vegetation communities in the Amazon floodplain. International Journal of Remote Sensing, 25(10), 1817-1835. http://dx.doi.org/10.1080/0143116031000116985.

Costa, M. P. F., Niemann, O., Novo, E., \& Ahern, F. (2002). Biophysical properties and mapping of aquatic vegetation during the hydrological cycle of the Amazon floodplain using JERS-1 and Radarsat. International Journal of Remote Sensing, 23(7), 1401-1426. http://dx.doi.org/10.1080/01431160110092957.

Engdahl, M., Minchella, A., Marinkovic, P., Veci, L., \& Lu, J. (2012). NEST: An esa open source toolbox for scientific exploitation of SAR data. International Geoscience and Remote Sensing Symposium (IGARSS), Vol. 1. (pp. 5322-5324). http://dx.doi.org/10. 1109/IGARSS.2012.6352406

Evans, T. L., \& Costa, M. (2013). Landcover classification of the Lower Nhecol??ndia subregion of the Brazilian Pantanal Wetlands using ALOS/PALSAR, RADARSAT-2 and ENVISAT/ASAR imagery. Remote Sensing of Environment, 128, 118-137. http://dx. doi.org/10.1016/j.rse.2012.09.022

Ferreira-Ferreira, J., Silva, T. S. F., Streher, A. S., Affonso, A. G., Furtado, L. F., de A. Forsberg, B. R., \& Novo, E. M. L. M. (2014). Combining ALOS/PALSAR derived vegetation structure and inundation patterns to characterize major vegetation types in the Mamirauá Sustainable Development Reserve, Central Amazon floodplain, Brazil. Wetlands Ecology and Management. http://dx.doi.org/10.1007/s11273-014-9359-1.

Freeman, A., \& Durden, S. L. (1998). A three-component scattering model for polarimetric SAR data. IEEE Transactions on Geoscience and Remote Sensing, 36(3), 963-973. http:// dx.doi.org/10.1109/36.673687.

Furtado, L. F., Silva, de A., Fernandes, T. S. F., Novo, P. J. F., \& de M., E. M. L. (2015). Land cover classification of Lago Grande de Curuai floodplain (Amazon, Brazil) using multi-sensor and image fusion techniques. Acta Amazonica, 45(2), 195-202. http:// dx.doi.org/10.1590/1809- 4392201401439.

Garcia, C. E., Roberto, J., Mura, J. C., Johann, H., \& Kux, H. (2012). Análise do potencial de imagem TerraSAR-X para mapeamento temático no sudoeste da Amazônia brasileira. Acta Amazonica, 42(2), 205-214

Gosselin, G., Touzi, R. \& Cavayas, F. (2013). Polarimetric Radarsat-2 wetland classification using the Touzi decomposition: case of the Lac Saint-Pierre Ramsar wetland. Canadian Journal of Remote Sensing, 39(6), 491-506. http://dx.doi.org/10.5589/m14-002.

Henderson, F. M., \& Lewis, A. J. (2008). Radar detection of wetland ecosystems: A review. International Journal of Remote Sensing, 29(20), 5809-5835. http://dx.doi.org/10. 1080/01431160801958405.

Hess, L. L., Melack, J. M., Novo, E. M. L. M., Barbosa, C. C. F., \& Gastil, M. (2003). Dualseason mapping of wetland inundation and vegetation for the central Amazon Basin. Remote Sensing of Environment, 87(4), 404-428. http://dx.doi.org/10. 1016/j.rse.2003.04.001.

Hess, L. L., Melack, J. M., \& Simonett, D. S. (1990). Radar detection of flooding beneath the forest canopy - A review. International Journal of Remote Sensing, 11(7), 1313-1325.

Hess, L. L., Melack, J. M., Filoso, S., \& Yong, Wang (1995). Delineation of inundated area and vegetation along the Amazon floodplain with the SIR-C synthetic aperture radar. IEEE Transactions on Geoscience and Remote Sensing, 33(4), 896-904. http:// dx.doi.org/10.1109/36.406675

Hess, Laura L., Melack, John M., Affonso, Adriana G., Barbosa, Claudio, Gastil-Buhl, Mary, \& M. L. M, Novo, Evlyn (2015). Wetlands of the Lowland Amazon Basin: Extent. VegetativeCover, and Dual-season Inundated Area as Mapped with JERS-1 Synthetic ApertureRadar. Wetlands, 35(4), 745-756.

Jiao, X., Kovacs, J. M., Shang, J., McNairn, H., Walters, D., Ma, B., \& Geng, X. (2014). Objectoriented crop mapping and monitoring using multi-temporal polarimetric RADARSAT-2 data. ISPRS Journal of Photogrammetry and Remote Sensing, 96, 38-46. http://dx.doi.org/10.1016/j.isprsjprs.2014.06.014.

Jarvis, A., Reuter, H. I., \& Nelson, A. (2008). Hole-filled SRTM for the globe version 4. available from the CGIAR-CSI SRTM 90 m Database http://srtm.csi.cgiar.org

Junk, W. J. (1997). The Central Amazon floodplain - Ecology of a pulsing system. Verlag: Springer (548 pp.).

Junk, W. J., Bayley, P. B., \& Sparks, R. E. (1989). The flood pulse concept in river-floodplain systems. Canadian Special Publication of Fisheries and Aquatic Sciences, 106(1), 110-127. http://dx.doi.org/10.1371/journal.pone.0028909.

Junk, W. J., Piedade, M. T. F., Schöngart, J., \& Wittmann, F. (2012). A classification of major natural habitats of Amazonian white-water river floodplains (várzeas). Wetlands 
Ecology and Management, 20(6), 461-475. http://dx.doi.org/10.1007/s11273-0129268-0.

Kasischke, E. S., Melack, J. M., \& Dobson, M. C. (1997). The use of imaging radars for ecological applications - A review. Remote Sensing of Environment, 59(2), 141-156. http://dx.doi.org/10.1016/S0034-4257(96)00148-4

Koch, M., Schmid, T., Reyes, M., \& Gumuzzio, J. (2012). Evaluating full polarimetric C- and L-band data for mapping wetland conditions in a semi-arid environment in central Spain. IEEE Journal of Selected Topics in Applied Earth Observations and Remote Sensing, 5(3), 1033-1044. http://dx.doi.org/10.1109/JSTARS.2012.2202091.

Kwoun, O. -I., \& Lu, Z. (2009). Multi-temporal RADARSAT-1 and ERS backscattering signatures of coastal wetlands in southeastern Louisiana. Photogrammetric Engineering and Remote Sensing, 75(5), 607-615 (Retrieved from http://www.asprs.org/publications/ pers/2009journal/may/abstracts.html\#607).

Lang, M. W., Townsend, P. a., \& Kasischke, E. S. (2008). Influence of incidence angle on detecting flooded forests using C-HH synthetic aperture radar data. Remote Sensing of Environment, 112(10), 3898-3907. http://dx.doi.org/10.1016/j.rse.2008.06.013.

Lee, J. S., \& Pottier, E. (2009). Polarimetric radar imaging: From basics to applications. Boca Raton: CRC Press (440 pp.).

Lee, J. S., Grunes, M. R., \& Pottier, E. (2001). Quantitative comparison of classification capability: Fully polarimetric versus dual and single-polarization SAR. IEEE Transactions on Geoscience and Remote Sensing, 39(11), 2343-2351. http://dx.doi. org/10.1109/36.964970.

Liaw, A., \& Wiener, M. (2002). Classification and regression by randomForest. $R$ News, 2(3), 18-22.

Marti-Cardona, B., Lopez-Martinez, C., Dolz-Ripolles, J., \& Bladè-Castellet, E. (20101). ASAR polarimetric, multi-incidence angle and multitemporal characterization of Doñana wetlands for flood extent monitoring. Remote Sensing of Environment, 114(11), 2802-2815. http://dx.doi.org/10.1016/j.rse.2010.06.015.

Martinez, J. M., \& Le Toan, T. (2007). Mapping of flood dynamics and spatial distribution of vegetation in the Amazon floodplain using multitemporal SAR data. Remote Sensing of Environment, 108(3), 209-223. http://dx.doi.org/10.1016/j.rse.2006.11.012.

Melack, J. M., \& Hess, L. L. (2010). Remote sensing of the distribution and extent of wetlands in the Amazon Basin. In W. J. Junk, M. T. F. Piedade, F. Wittmann, J. Schöngart, \& P. Parolin (Eds.), Amazonian floodplain forests: Ecophysiology, biodiversity and sustainable management (pp. 43-59). Springer. http://dx.doi.org/10.1007/978-90-481-8725-6.

Millard, K., \& Richardson, M. (2013). Wetland mapping with LiDAR derivatives, SAR polarimetric decompositions, and LiDAR-SAR fusion using a random forest classifier. Canadian Journal of Remote Sensing, 39(4), 290-307. http://dx.doi.org/10.5589/m13-038.

Pontius, R. G., \& Millones, M. (2011). Death to Kappa: Birth of quantity disagreement and allocation disagreement for accuracy assessment. International Journal of Remote Sensing, 32(15), 4407-4429. http://dx.doi.org/10.1080/01431161.2011.552923.

Pottier, E., Ferro-Famil, L., Allain, S., Cloude, S., Hajnsek, I., Papathanassiou, K., ... Desnos, Y. L. (2009i). Overview of the PolSARpro v4.0 Software. The open source toolbox for polarimetric and interferometric polarimetric SAR data processing. International Geoscience and Remote Sensing Symposium (IGARSS), Vol. 4. (pp. 936-939). http:// dx.doi.org/10.1109/IGARSS.2009.5417532.

Qi, Z., Yeh, A. G. -O., Li, X., \& Lin, Z. (2012). A novel algorithm for land use and land cover classification using RADARSAT-2 polarimetric SAR data. Remote Sensing of Environment, 118, 21-39. http://dx.doi.org/10.1016/j.rse.2011.11.001.

Renó, V. F., Novo, E. M. L. M., Almeida-Filho, R., \& Suemitsu, C. (2011a). Mapeamento da antiga cobertura vegetal de várzea do Baixo Amazonas a partir de imagens históricas
(1975-1981) do Sensor MSS-Landsat. Acta Amazonica, 41(1), 47-56. http://dx.doi org/10.1590/S0044-59672011000100006.

Renó, V. F., Novo, E. M. L. M., Suemitsu, C., Rennó, C. D., \& Silva, T. S. F. (2011b). Assessment of deforestation in the lower Amazon floodplain using historical Landsat MSS/TM imagery. Remote Sensing of Environment, 115(12), 3446-3456. http://dx.doi.org/10. 1016/j.rse.2011.08.008.

Rudorff, C. M., Melack, J. M., \& Bates, P. D. (2014). Flooding dynamics on the lower Amazon floodplain: 1. Hydraulic controls on water elevation, inundation extent, and river-floodplain discharge. Water Resources Research, 50(1), 619-634. http://dx.doi. org/10.1002/2013WR014091.

Sartori, L. R., Imai, N. N., Mura, J. C., Novo, E. M. L. D. M., \& Silva, T. S. F. (2011). Mapping macrophyte species in the amazon floodplain wetlands using fully polarimetric ALOS/PALSAR data. IEEE Transactions on Geoscience and Remote Sensing, 49(12 PART 1), 4717-4728. http://dx.doi.org/10.1109/TGRS.2011.2157972.

Silva, T. S. F., Costa, M. P. F., \& Melack, J. M. (2010). Spatial and temporal variability of macrophyte cover and productivity in the eastern Amazon floodplain: A remote sensing approach. Remote Sensing of Environment, 114(9), 1998-2010. http://dx.doi.org/10. 1016/j.rse.2010.04.007.

Silva, T. S. F., Costa, M. P. F., Melack, J. M., \& Novo, E. M. L. M. (2008). Remote sensing of aquatic vegetation: Theory and applications. Environmental Monitoring and Assessment, 140(1-3), 131-145. http://dx.doi.org/10.1007/s10661-007-9855-3.

Silva, T. S. F., Melack, J. M., Streher, A. S., Ferreira-Ferreira, J., \& de A. Furtado, L. F. (2015, ) Capturing the dynamics of Amazonian wetlands using synthetic aperture radar: Lessons learned and future directions. In R. Tiner, M. Lang, \& V. Klemas (Eds.), Remote sensing of wetlands: Applications and advances (pp. 453-470). Boca Raton, Florida: CRC Press. http://dx.doi.org/10.1201/b18210-25.

Touzi, R. (2007). Target scattering decomposition in terms of roll-invariant target parameters. IEEE Transactions on Geoscience and Remote Sensing, 45(1), 73-84. http://dx.doi. org/10.1109/TGRS.2006.886176.

USGS (2009). Global land survey, 2000, Landsat TM, 30 m scene LT52280612009280CUB01. Sioux Falls, South Dakota: USGS.

Van Beijma, S., Comber, A., \& Lamb, A. (2014). Random forest classification of salt marsh vegetation habitats using quad-polarimetric airborne SAR, elevation and optical RS data. Remote Sensing of Environment, 149, 118-129. http://dx.doi.org/10.1016/j.rse. 2014.04.010.

Van Zyl, J. J. (1992). Application of Cloude's target decomposition theorem to polarimetric imaging radar data. Radar polarimetry, SPIE-1748 (pp. 184-212).

Wittmann, F., Junk, W. J., \& Piedade, M. T. F. (2004). The várzea forests in Amazonia: Flooding and the highly dynamic geomorphology interact with natural forest succession. Forest Ecology and Management, 196(2-3), 199-212. http://dx.doi.org/10.1016/j. foreco.2004.02.060.

Wittmann, F., Schöngart, J., \& Junk, W. J. (2010). Phytogeography, species diversity, commynity structure and dynamics of central Amazonian floodplain forests. In W. J. Junk, M. T. F. Piedade, F. Wittmann, J. Schöngart, \& P. Parolin (Eds.), Amazonian floodplain forests: Ecophysiology, biodiversity and sustainable management (pp. 61-102) Springer. http://dx.doi.org/10.1007/978-90-481-8725-6.

Yamaguchi, Y., Yajima, Y., \& Yamada, H. (2006). A four-component decomposition of POLSAR images based on the coherency matrix. IEEE Geoscience and Remote Sensing Letters, 3(3), 292-296. http://dx.doi.org/10.1109/LGRS.2006.869986. 